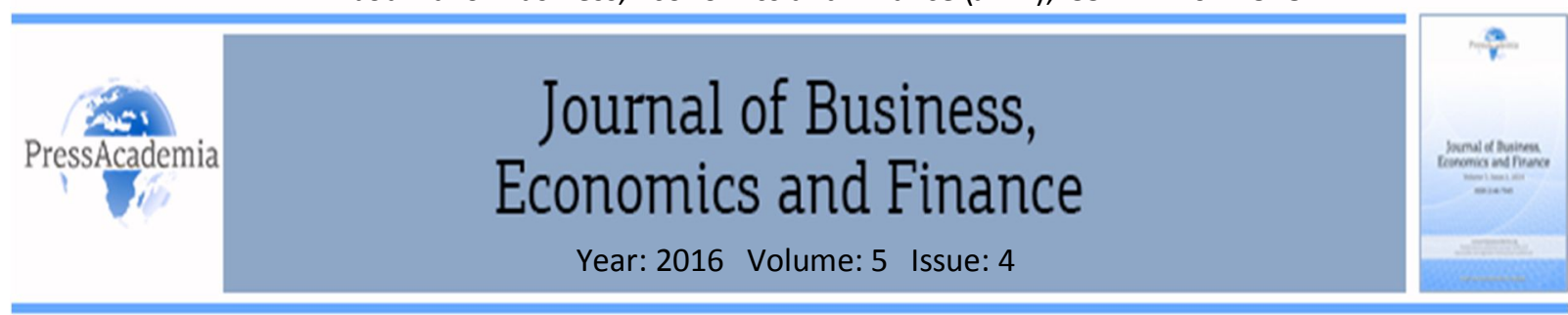

\title{
THE VIABILITY OF RESIDENTIAL GRID-CONNECTED SOLAR PHOTOVOLTAIC SYSTEMS IN THE STATE OF INDIANA
}

DOI: 10.17261/Pressacademia.2017.360

\author{
Mahmoud Al-Odeh ${ }^{1}$, Marion Schafer ${ }^{2}$, M. Affan Badar ${ }^{3}$, Randy Peters ${ }^{4}$ \\ ${ }^{1}$ Bemidji State University. malodeh@bemidjistate.edu \\ ${ }^{2}$ Indiana State University, marion.schafer@indstate.edu \\ 3indiana State University.m.affan.badar@indstate.edu, University of Sharjah. mbadar@sharjah.ac.ae \\ ${ }^{4}$ Indiana State University. randy.peters@indstate.edu
}

\begin{abstract}
While the use of green energy has gained popular support and efforts have been made to market it, few studies have investigated the economic advantages and the savings that could be gained by implementing green solutions for energy challenges. This study aims to measure the financial viability of installing and using a residential grid-connected photovoltaic (PV) system in the State of Indiana while predicting its performance in eighteen geographical locations within the state over the system's expected lifetime. A systematic approach of six steps was used to collect and analyze the data. The analysis has been condcutded using engineering economic methods including payback period, net present value (NPV) and internal rate of return (IRR). It has been found that installing a PV system for a single family residence in the State of Indiana will not pay for itself within 25 years assuming the average cost of a system. The government incentive programs are not enough to offset the cost of installing the system against the cost of the electricity that would not be purchased from the utility company.
\end{abstract}

Keywords: Net present value, internal rate of return, payback period, residential solar PV system, renewable energy, State of Indiana. JEL Classification: $022, \mathrm{Q} 28, \mathrm{Q} 42$

\section{INTRODUCTION}

Different types of renewable energy are increasingly being used throughout the world to meet the growing demand for energy. Tremendous efforts have been invested in the United States to improve residents' awareness of the use of such resources as wind, solar, and biomass energy. In recognition of this fact, the U.S. government, in general, and the state of Indiana, in specific, has offered a number of incentive programs that help reduce the costs of installing renewable systems to make these systems more affordable for the residents (Nemet, 2009; Diamond, 2009).

Among the solar systems available, photovoltaic (PV) systems would allow households to produce their own electricity with little noise or air pollution (Tsoutsos, Frantzeskaki \& Gekas, 2005; Turney \& Fthenakis, 2011). In order for a PV system to become a practical solution for Indiana residents, it must be perceived as attractive financial investments for its owners. The lack of knowledge regarding the economic assessment of installing and using a residential grid-connected PV system has resulted in a low number of homeowners installing the systems in the state. In order to address this knowledge gap, this study aims to measure the financial viability of installing and using a residential grid-connected PV system in the State of Indiana while predicting its performance in different geographical locations within the state over the system's expected lifetime. The study has taken time value of money, system maintenance (e.g. convertor replacement every 10 years), and future electricity price increases into consideration. 


\section{DATA AND METHODOLOGY}

This section describes the goals, questions, assumptions, tools, procedures and methodology of this research work.

\subsection{Goals and Objectives}

This research aims, first, to determine the suitable and standard size of a residential PV system for average Indiana households. Second, to estimate the energy generation of a standard PV system and determine areas with high solar potential. Third, to gain understanding of the economic benefits of using a standard PV system. Also, it aims to identify the factors that should be considered when determining the economic payoff of installing and using a PV system in terms of electricity rate, system performance, and incentives. The fifth goal of this research is to use US Department of Energy recommendations and methodologies to develop a model for building a standard PV system. Evaluating the current policies toward installing a standard residential PV system in the state of Indiana is the sixth goal of this reserach. Finally, this reaerch aims to determine the areas suitable for installing a commercial PV system in the State of Indiana.

By achieving the goals and objectives that are mentioned above, the following questions can be answered: What is the precise size of a PV system suitable for a typical single family home in Indiana?; How much does a standard PV system cost?; Does the government subsidy programs i.e. federal tax credit make the system financially attractive investment to Indiana homeowners?; and what is the payback period and the internal rate of return for a standard PV system?

\subsection{Statement of Purpose}

This study aims to measure the financial viability for a residential grid-connected PV system in the State of Indiana. In order to evaluate the financial feasibility of typical residential grid-connected PV systems in the State of Indiana, data regarding the counties of Indiana State should be collected, evaluated, and analyzed through mathematical models and formulas. In addition, information about prices and the size of a typical system should be collected from the professionals and representatives who work in the PV industry via online quotes.

\subsection{Assumptions}

This study is conducted based on the following eleven assumptions: 1) the PV system is assumed to be integrated within the utility grid, eliminating the need for investing in batteries or an electrical storage system; 2) the data obtained using the PV Watt application, a performance calculator for on-grid PV systems, is assumed to be an accurate predictor; 3 ) the analysis period for this study is 25 years because the warranty that is provided by the PV professionals in Indiana is 25 years (Energysage, 2016), so it assumed that is a reasonable lifetime (Lagorse, Paire \& Miraoui, 2009; Branker, Pathak \& Pearce, 2011); 4) the market interest rate will remain steady at $3 \%$ (Indiana Department of Revenue, 2012); 5 ) it is assumed that the net metering program is available in all the areas and for all the residents of Indiana; 6) it is assumed that PV energy production degradation is equal to 3\% per year based on the literature (Energy Efficiency \& Renewable Energy, 2008; ElBassiouny \& Mohamed, 2012; Jha, 2010); 7) it is assumed that the end of life decommissioning cost is equal to end of life salvage price; 8 ) it is assumed that the average electricity cost will increase in a constant pattern over the lifetime of the system at an annual rate of $1.052 \%$ based on the literature (U.S. Energy Information Administration, 2012; Edison Electric Institute, 2006; Indiana Utility Regulatory Commission, 2012; Americas Power, 2012); 9) it is assumed that the selected counties, which are the counties with the highest population in each geographical area, are typical of that area of the state of Indiana; 10) it is assumed that tilt is equal to latitude and azimuth is equal to true south to avoid shading; 11 ) and it is also assumed that a typical single family in the state of Indiana consumes 11000 kWh / year (Energy Efficiency and Renewable Energy Clearinghouse, 2012).

\subsection{Statement of Limitations}

One limitation of this study is that changes may occur over time that may make the results time sensitive. 


\subsection{Research Tools}

The study utilized the following methods, tools, and applications:

1. PV Watts application: The PV Watt is a computer simulation application developed by the U.S Department of Energy to predict the energy production and cost savings of grid-connected photovoltaic (PV) energy systems throughout the world (Safaei, Freire, \& Antunes, 2013; Dobos, 2014).

2. Google Earth: Google Earth is an application that provides geographical information regarding locations. Microsoft Excel: Microsoft Excel is a software package used to produce spreadsheets and graphs and perform mathematical functions and calculations.

3. Online quoting: Via their websites, PV system providers were requested to provide online quotes of the size, necessary components and their costs, maintenance expenses, and lifetime of a standard single family residential PV system.

4. Zip Code finder: The Zip Code Finder is a general web application offered by many websites to identify the zip code of a specific area for the counties in the State of Indiana.

\subsection{Research Design Methodology and Procedures}

This study has employed a systematic approach to collect data via reviewing the relevant literature, requesting information about the system's cost from PV professionals, collecting data about the Indiana cities location, using a computer simulation program called PV Watt Calculator to estimate a standard system's performance, and then evaluating and analyzing the collected data using engineering economic methods, including breakeven, cash flow analyses, net present value, and internal rate of return, to determine the economic features of the system. The following explanation for each step:

\section{Step One: Reviewing relevant literature}

Reviewing the literature was important to identify electricity usage of a typical house and the average electricity rates increase in the State of Indiana. This study only considers the real increase in electricity prices during the period of 2005-2011 without considering the impact of the new EPA regulations. Table 1 shows the average electric rates in the State of Indiana between 2005 and 2011. Also, from the table, it can be found that the average increase in electricity rates is $1.052 \%$. This rate is used in this study to measure the impact of future increase in electricity prices on the economic performance for the standard PV system.

Table 1: The Average Electric Rates in the State of Indiana, 2005-2011

\begin{tabular}{|l|l|l|}
\hline Year & $\begin{array}{l}\text { Price } \\
\text { (Cents/KWh) }\end{array}$ & $\begin{array}{l}\text { The } \\
\text { increase }\end{array}$ \\
\hline 2005 & 7.5 & \\
\hline 2006 & 8.22 & $1.096 \%$ \\
\hline 2007 & 8.26 & $1.01 \%$ \\
\hline 2008 & 8.87 & $1.074 \%$ \\
\hline 2009 & 9.5 & $1.07 \%$ \\
\hline 2010 & 9.56 & $1.01 \%$ \\
\hline 2011 & 10.06 & $1.05 \%$ \\
\hline \multicolumn{2}{|l|}{ The average increase } & $1.052 \%$ \\
\hline
\end{tabular}

Source: U.S. Energy Information Administration, 2012.

The Energy Efficiency and Renewable Energy Clearinghouse (2012) estimates the average yearly energy consumption for a typical home according to the 23 appliances described in Table 2.

Table 2: The Average Energy Consumption for a Typical Home

\begin{tabular}{|l|l|l|}
\hline Appliance & Time in use & kWh / year \\
\hline Air Conditioner (one ton) & 4 hrs / day, 180 days/ yr & 2278 \\
\hline Clock radio & 24 hours / day & 44 \\
\hline
\end{tabular}




\begin{tabular}{|l|l|l|}
\hline Clothes washer (does not include hot water) & 2 hours / Week & 31 \\
\hline Coffee maker & 30 minute / day & 128 \\
\hline Dehumidifier & 12 hours / day & 700 \\
\hline Dishwasher (does not include hot water) & 1 hour / day & 532 \\
\hline Electric blanket & $8 \mathrm{hrs} /$ day, 120 days / yr & 175 \\
\hline Fan (furnace) & 12 hrs / day,120 days / yr & 432 \\
\hline Fan (whole house) & $4 \mathrm{hrs} /$ day, 120 days / yr & 270 \\
\hline Fan (window) & 4 hrs / day,180days / yr & 144 \\
\hline Hair dryer & 15 minutes / day & 100 \\
\hline Heater (portable) & 6 hours / day,120 days / yr & 1240 \\
\hline Iron & 1 hour/week & 52 \\
\hline Microwave oven & 2 hours/week & 89 \\
\hline Radio (stereo) & 2 hours / day & 73 \\
\hline Range (with self-cleaning) & 2 hours/ day & 775 \\
\hline Refrigerator (frost free 16 cubic feet) & 24 hours / day & 642 \\
\hline Television & 4 hours / day & 292 \\
\hline Toaster & 1 hour / day & 73 \\
\hline Vacuum cleaner & 1 hour / week & 38 \\
\hline VCR & 4 hours / day & 30 \\
\hline Water bed (no cover) & 12 hrs / day,180 days / yr & 620 \\
\hline Water heater (40 gallon) & 2 hrs / day & 2190 \\
\hline & Total & 10948 \\
\hline
\end{tabular}

Source: Energy Efficiency and Renewable Energy Clearinghouse, 2012

\section{Step Two: Identifying the standard system's size and specification}

Data regarding the costs of installing a standard system was collected by requesting online quotes from PV professionals via their websites. The names and the websites of PV manufacturers, distributers, dealers, and repair specialists were identified using the key phrase "Solar System" and the location of "Indiana" to search the electronic version of the Yellow Book. The results were then filtered by selecting the following three categories:

1. Solar Energy Equipment and Systems-Dealers;

2. Solar Energy Equipment and Systems-Service and Repair; and

3. Solar Energy Equipment and Systems-Manufacturers and Distributors.

The online quotes provided data regarding required components and their costs, size, maintenance costs, and expected lifetime, necessary to address the following questions:

A. Components and costs:

1. What are the major components of a grid-connected PV system?

2. What is the cost of each component and its installation, and on what basis is the cost determined?

B. Performance:

1. How the electrical performance of PV modules and arrays is typically rated?

2. How should a PV array be oriented for maximum energy production?

C. Size

1. What is the surface area that is required for installing a PV array?

D. Maintenance

1. What is the estimated annual maintenance cost of a standard PV system?

E. Lifetime

1. What is the expected lifetime of a standard PV system? 


\section{Step Three: Selecting the cities and locations}

The third step in the research methodology was identifying the cities and counties of Indiana. According to the State of Indiana website (IN.gov, 12; IN.gov, 13), the counties are grouped into the six geographical regions of North, East, West, Central, South Central, and South. The counties within each group were sorted based on the population and then the county with the highest population within each group was selected to represent the geographical region, as it is most representative of the greatest number of Indiana residents in that region. By using this procedure, it may be easier to target the most populous locations where the findings can be made known to the greatest number of residents, which will facilitate the study goal of increasing awareness of PV systems among the greatest number of Indiana residents possible.

\section{Step Four: Finding the potential solar power based on the location}

The next step was identifying the zip codes and the cities within each of the selected counties (regions of the state) using the Zip Code Finder application. Identification of the zip codes for each city was used to collect precise geographical data, including solar power potential, that affect the amount of electricity that can be generated via a standard PV system located in a particular area. More than one location within each of the six selected counties with different latitudes and longitudes were used (see later, Table 6). The reason for selecting more than one location is to have a more accurate results that show the generated energy at multiple locations in the county. Google Earth application was used to determine the solar azimuth and solar altitude, two parameters necessary to identify the exact locations for each zip code to determine the solar power potential for each area. More details can be found in Al-Odeh (2013).

\section{Step Five: Estimating the system's performance}

The fifth step was entering the geographical parameters (solar azimuth and solar altitude) and the system specifications (which gathered from PV professionals) into the PV Watt application to calculate the amount of energy that can be produced using a standard PV system. The application will show the cost of electricity for a particular area in terms of rate per kilowatt hour. If the area is not covered by any utility provider, it will show the rate for the nearest utility service area.

\section{Step Six: Conducting the economic assessment}

Once the technical requirements of the standard PV system have been stated, the economic analysis, which was the final step in the research methodology, carried out. The economic assessment included both costs and benefits of the system. The economic assessment was conducted by using Excel spreadsheets for calculation of the financial parameters, including cash flows, project balance (PB), net present value (NPV), and internal rate of return (IRR).

The PB starts with negative values in this case as it is an investment project in a PV system. The project balance (PB) for the year 0 is equal to the cash flow (CF) for year 0 , and it is equal to initial cost and the installation costs (Al-Odeh, Stergioulas, \& Badar, 2012). For the remaining years, PB can be calculated by multiplying PB of the previous year $(t-1)$ by $(1+$ interest rate $i)$ and adding CF of that year $(t)$ (Newnan, Eschenbach, \& Lavelle, 2011; Rosen \& Dincer, 2003; Dasgupta \& Stiglitz, 1974).

$\mathrm{PB}_{t}=\left[\mathrm{PB}_{t-1} *(1+i)\right]+\mathrm{CF}_{t}$

If $\mathrm{PB}$ reaches 'zero' at a particular time while changing from negative to positive values, this time is referred to as discounted payback period (DPP). If PB remains negative till the end of the analysis period (i.e., $n=25$ years) meaning the project is not justified economically (Newnan, Eschenbach, \& Lavelle, 2011).

Project balance (PB) helps to determine the discounted payback period (DPP). PB vs time (year) can be plotted to determine the discounted payback period (DPP). The DPP over 25 years has been calculated along with the internal rate of return (IRR) and the net present value (NPV) or present worth (PW). IRR is the interest rate (i*) at which the project benefits are equivalent to the project costs or the present worth (PW) of the project is zero. IRR (i.e., i*) can be obtained by solving Equation 2 for i*. 
$\mathrm{NPV}\left(i^{*}\right)=\mathrm{PW}\left(\mathrm{i}^{*}\right)=0=\mathrm{PW}\left(\mathrm{i}^{*}\right)_{\text {benefit }}-\mathrm{PW}\left(\mathrm{i}^{*}\right)_{\text {cost }}=\sum_{t=0}^{n} C F_{t}\left(1+i^{*}\right)^{-t}$

NPV or net PW or PW represents an equivalent amount of the project cash flows at $t=0$ (i.e., present time) at interest rate (i) (Newnan, Eschenbach, \& Lavelle, 2011; Khan, \& Iqbal, 2005). NPV can also be computed from a range of cash flows (from period 1 to $n$ ) using the NPV function in the Microsoft Excel as given below (Newnan, Eschenbach, \& Lavelle, 2011).

NPV:=NPV(rate, values)

If any cash flow occurs at $n=0$, it is added algebraically to the value obtained from Equation 3 in the excel NPV function. If NPV is less zero, the project is concluded to be not justified (Kim, Y. H., Philippatos, \& Chung, 1986; De Reyck, Degraeve \& Vandenborre, 2008).

IRR can also be computed from a range of cash flows (from period 0 to $n$ ) using the IRR function in the Microsoft Excel as given below (Newnan, Eschenbach, \& Lavelle, 2011). If IRR is less than market interest rate or MARR, the project is concluded to be not justified.

IRR:=IRR(values, [guess])

Thus, DPP, values of PB at $n=25$, and NPV and IRR for $n=25$ were used to evaluate the economic feasibility of installing a grid-connected PV. The total system's cost (which was collected from PV professionals) and the projected cash flows (which were based on analysis of system costs, expected energy production, electricity rate, maintenance expenses, expected lifetime, and interest rate) were the two most important factors for conducting this analysis. Figure 1 shows the process that was used to make the economic assessment for the standard PV system.

Figure 1: The Process of Making the Economic Assessment for the Standard PV System

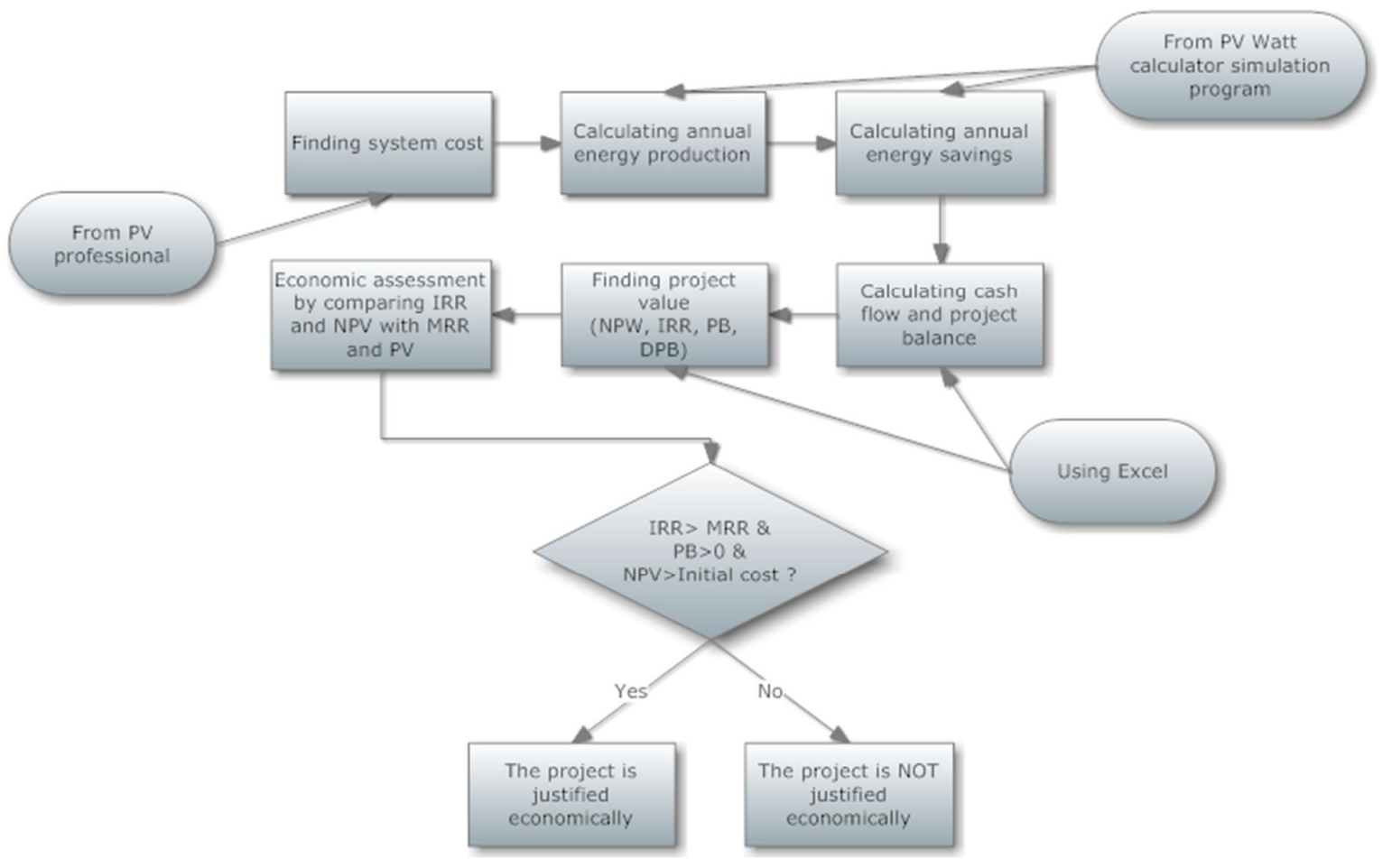


Figure 2: Research Methodology

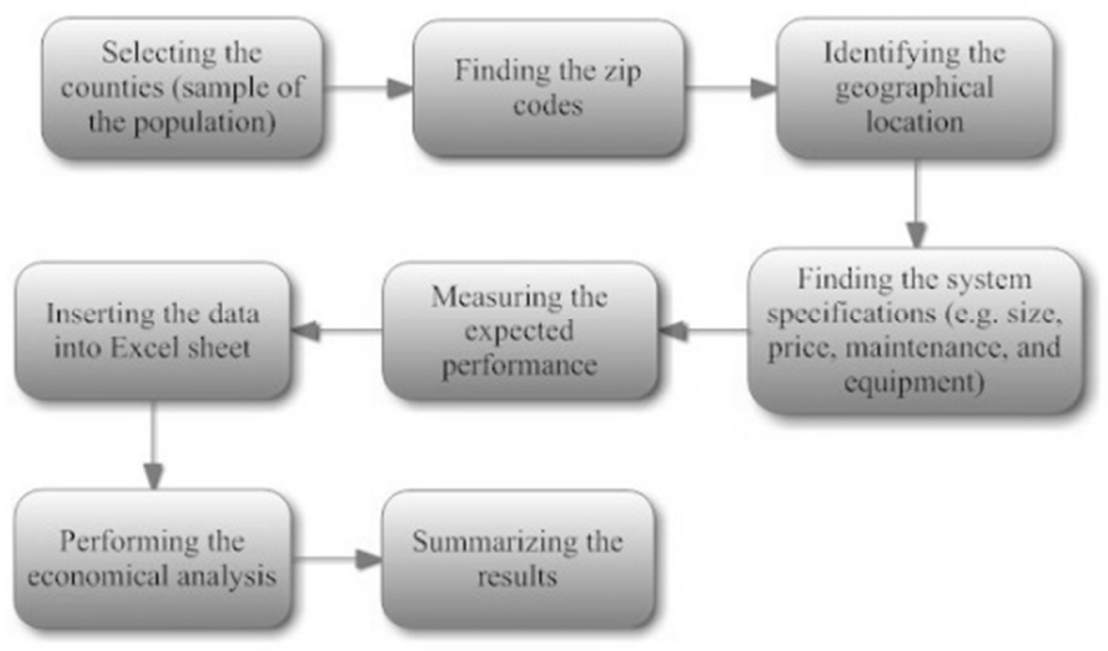

\section{FINDINGS AND DISCUSSIONS}

This section describes the research finding details including: system and cost specification, system efficiency, and the economic analysis in each Indiana location studied.

\subsection{The Selected Locations and the Amount of Electricity Generation}

After identifying the locations, potential solar power and the system performance were calculated. Figure 3 summarizes the electricity that could be generated by a standard PV system in all of the selected locations.

Figure 3: Electricity Generation by a Standard PV System in the Selected Locations

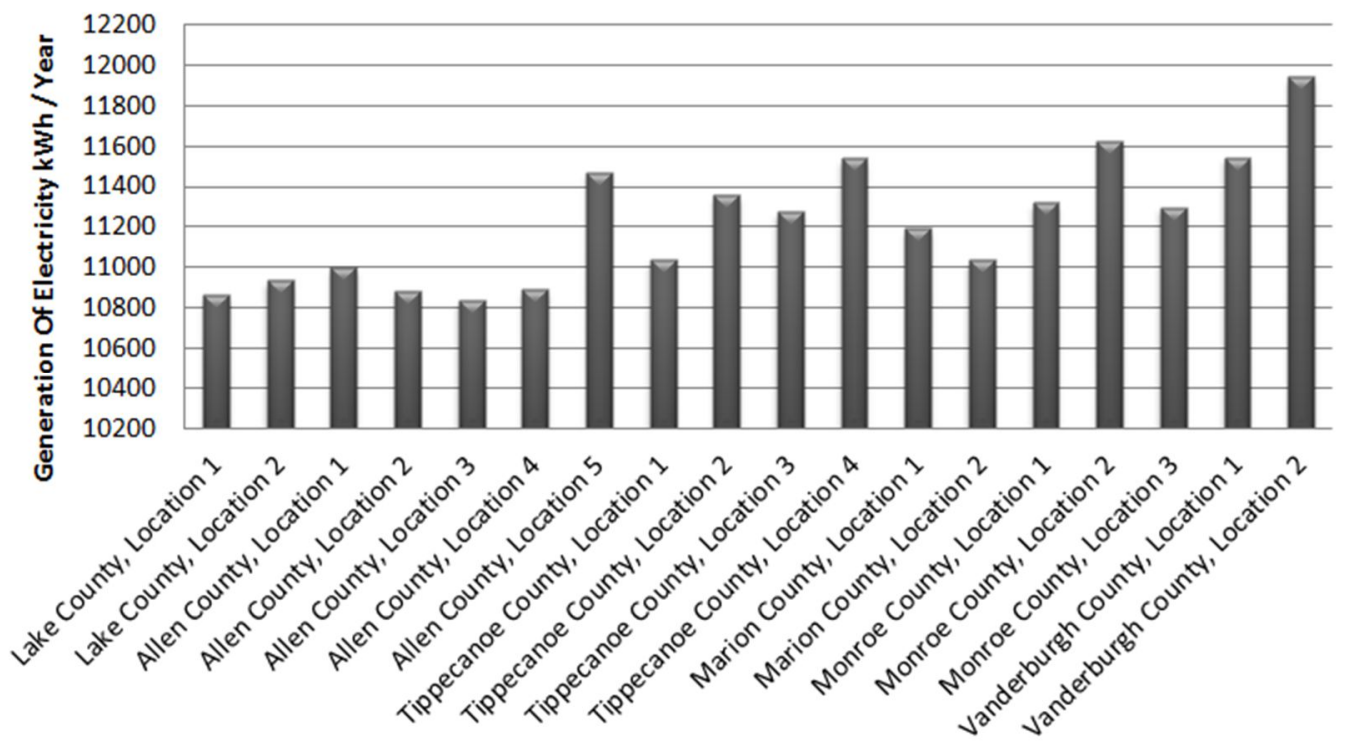

\subsection{The System Specification}

PV professionals in the State of Indiana estimated a standard size of a PV system suitable for an average single family home in Indiana, to be $9.36 \mathrm{KW}$. The system consists of 36 panels of $260 \mathrm{~W}$ each and enables a 
household to generate $11,000 \mathrm{kWh}$ per year. The system is enough to supply a typical house in Indiana with the needs of electricity. Installing this system could eliminate the need for buying electricity by up to $100 \%$ because it generates all the electricity needed, and excess electricity could be sold back to the electric utility to offset power needed at night.

Table 3: System Specifications

\begin{tabular}{|l|l|}
\hline \multicolumn{2}{|c|}{ PV System Specifications } \\
\hline DC Rating & $9.36 \mathrm{~kW}$ \\
\hline DC to AC Derate Factor & 0.77 \\
\hline AC Rating & $7.21 \mathrm{~kW}$ \\
\hline Array Tilt & $32.0^{\circ}$ \\
\hline Array Azimuth & $180.0^{\circ}$ \\
\hline Array Type & Fixed Tilt \\
\hline Weight per Panel & $46.7 \mathrm{lbs}$ \\
\hline Panel Width & 39.41 \\
\hline Panel Length & 65.94 \\
\hline Total Panels & 36 \\
\hline
\end{tabular}

Source: Interviewing several industrial professionals in a focus group session

\subsection{The Cost Specifications}

The cost of a standard PV system varies from one manufacturer to another and depends on the system's configuration (e.g., roof or ground mounted, accessories...). The data regarding the system component and the rates have been collected via the process of requesting online quotes. Quotes were obtained from 13 of the 23 providers with online quotes capability. The rates for the system components are summarized in Table 4.

Table 4: The Rates for the Solar System Parts

\begin{tabular}{|c|c|c|c|}
\hline Provider & Solar Panels Price (\$ per W) & Inverter & $\begin{array}{c}\text { Racking, Mounting, Wires, and } \\
\text { Accessories }\end{array}$ \\
\hline 1 & $\$ 1.59$ & $\$ 2,543.21$ & $\$ 140.72$ \\
\hline 2 & $\$ 1.89$ & $\$ 2,646.15$ & $\$ 55.12$ \\
\hline 3 & $\$ 2.13$ & $\$ 2,785.19$ & $\$ 57.23$ \\
\hline 4 & $\$ 2.43$ & $\$ 2,841.03$ & $\$ 64.46$ \\
\hline 5 & $\$ 2.28$ & $\$ 2,895.00$ & $\$ 75.55$ \\
\hline 6 & $\$ 2.53$ & $\$ 2,842.53$ & $\$ 65.61$ \\
\hline 7 & $\$ 2.63$ & $\$ 2,449.77$ & $\$ 76.73$ \\
\hline 8 & $\$ 2.80$ & $\$ 2,510.45$ & $\$ 87.83$ \\
\hline 9 & $\$ 2.75$ & $\$ 2,527.69$ & $\$ 90.91$ \\
\hline 10 & $\$ 3.13$ & $\$ 2,357.90$ & $\$ 99.03$ \\
\hline 11 & $\$ 3.43$ & $\$ 2,391.50$ & $\$ 100.09$ \\
\hline 12 & $\$ 3.89$ & $\$ 1,789.50$ & $\$ 91.10$ \\
\hline 13 & $\$ 4.45$ & $\$ 3,089.50$ & $\$ 124.14$ \\
\hline Average & $\$ 2.76$ & $\$ 2589.96$ & $\$ 86.81$ \\
\hline Total & $\$ 25869.60$ (for $9.36 \mathrm{KW})$ & $\$ 2,589.96$ & $\$ 781.28$ (for 9 racks) \\
\hline Total Cost & \multicolumn{3}{|c|}{$\$ 29,240.84$} \\
\hline
\end{tabular}

Source: Interviewing several industrial professionals in a focus group session

The cost of the PV panels ranges from $\$ 1.59$ to $\$ 4.45$ per Watt. The average cost for installing a $9.36 \mathrm{~kW}$ system is $\$ 2.76$ per Watt. From the online quotes, the researcher found that the PV manufacturers in the State of Indiana provide a warranty of 25 years for the panels and 10 years for the inverter. The price of the inverter ranges from $\$ 1,789.5$ to $\$ 3,089.5$. The average price for an inverter is $\$ 2,589.96$. The maximum cost for a 
standard PV system is $\$ 44,882.22(4.45 * 9360+3089.5+140.72)$. The minimum cost is $\$ 16,727.02$ $(1.59 * 9360+1789.5+55.12)$. The average cost for a standard PV system is $\$ 29,240.84(\$ 25,869.60+\$ 2,589.96$ $+\$ 781.28)$. The average price was used in this study to calculate expected cash flows of the system. The system price includes 36 panels to generate kWh per year, one inverter, nine rack systems, accessories (e.g., wires, connectors, breakers, and switches...), and installation. There is no maintenance required for the system but it is suggested that a household buy a new inverter every 10 years.

Homeowners in the State of Indiana are eligible to receive a 30 percent federal tax credit for the installation of solar technologies (Solangi, Islam, Saidur, Rahim \& Fayaz, 2011; Wiser, Bolinger \& Barbose, 2007). The federal tax credit is Residential Renewable Energy Tax Credit and if a taxpayer owes less than the tax credit, the excess credit generally may be carried forward to next tax year. This tax credit reduced the average net cost for a standard system to $\$ 20,468.588$ (\$29,240.84 - $\$ 8,772.252)$. Other parameters that should be considered in the analysis process are the market interest rate $3 \%$ (according to Indiana Department of Revenue), production degradation is equal to $3 \%$ per year starting from the second year (Energy Efficiency \& Renewable Energy, 2008; El-Bassiouny \& Mohamed, 2012; Jha, 2010) and the yearly increase in the cost of electricity $1.052 \%$ (U.S. Energy Information Administration, 2012; Edison Electric Institute, 2006; Indiana Utility Regulatory Commission, 2012; Americas Power, 2012).

\subsection{The System Efficiency}

The efficiency of the system is called the DC to AC derate factor. According to U.S. Department of Energy (2012), the efficiency of the system (derate factor) is considered to be $77 \%$ (PV module nameplate DC rating= $0.95 *$ Inverter and transformer $=0.92 *$ Mismatch $=0.98 *$ Diodes and connections $=0.995 * \mathrm{DC}$ wiring $=0.98 * A C$ wiring $=0.99 *$ Soiling $=0.95 *$ System availability $=0.98 *$ Shading $=1.00 *$ Age $=1.00)$. In order to consider degradation factor, the system performance (electricity production) is reduced by $3 \%$ per year starting from the second year.

\subsection{Summary of the Analysis Parameters}

The analysis depends on the following parameters:

1- The average net cost of a standard system = total cost - federal taxes credit ( $30 \%$ of the total cost).

The average net cost of a standard system $=\$ 29,240.84-(\$ 29,240.84 * 30 \%)=\$ 29,240.84-\$ 8,772.252=$ $\$ 20,468.588$

2- Geographical location of an area (depends on solar azimuth and solar altitude).

3- Electricity cost (varies from area to other).

4- Sales Tax $=7 \%$.

5- The market interest according to Indiana Department of Revenue rate $=3 \%$.

6- The yearly increase in rates of electricity $=1.052 \%$.

7- Degradation factor $=3 \%$ starting from the second year (U.S. Department of Energy, 2012).

8- Yearly Maintenance $=0$.

9- Salvage value $=$ Decommissioning cost.

10-Array Tilt $=32^{\circ}$ (U.S. Department of Energy, 2012).

11-Array Azimuth $=180^{\circ}$ (U.S. Department of Energy, 2012).

12-Panels lifetime $=25$ years (According to the PV professionals in Indiana) (Energysage, 2016).

13-Inverter lifetime = 10 years (According to the PV professionals in Indiana) (Energysage, 2016).

\subsection{Description of Conducting the Engineering Economy Assessment}

The specifications mentioned above were used to economically evaluate the viability of the system. The calculation of the annual cost or savings from the PV system depends on how much electricity was generated per month or per year. Electricity generated from the system was computed based on the available solar potential of the counties of Indiana.

The interest rate is equal to 3\%, which calculated according to Indiana Department of Revenue. The electricity rates were computed according to the rates that are provided by the utility company that serves the area. The 
electricity cost is considered to increase $1.052 \%$ every year. Savings were computed by multiplying the electricity cost with the amount of electricity generated. It has been considered that the system efficiency is $77 \%$, which is the derate factor. Starting from the second year, degradation factor was considered to be equal to $3 \%$ per year. Cash flows and project balances for a standard system over an analysis period of 25 years are presented for each of the selected counties (regions of the state).

The cash flow at the end of the first year is the saving due to electricity generation multiplied by the state sales tax of $7 \%$. The cash flows for the remaining years have been computed by multiplying the cash flow for the previous year by 1.052 (to account for the $1.052 \%$ yearly increase in electricity cost) and by 0.97 (to account for a $3 \%$ yearly decrease in system efficiency or to count degradation factor). A household is advised to replace the inverter every 10 years. Therefore, assuming the inverter average cost remains the same during the system lifetime; $\$ 2,589.96$ was added to the project balance at the $10^{\text {th }}$ and $20^{\text {st }}$ year. An analysis period for this work has been calculated to be 25 years because the warranty for the system is 25 years. Project balance amounts were calculated using Equation (1), IRR was computed using the IRR spreadsheet function in Equation 4, and NPV was computed using the NPV function in the Microsoft Excel in Equation 3. If any cash flow occurs at $n=0$, it is added algebraically to the value obtained from Equation 3 in the excel NPV function.

\subsection{Conducting the Analysis}

This section explains the process for calculating the engineering economy parameters only for the first location in the Lake County, Indiana. The system in this location can generate $10864 \mathrm{kWh}$ in the first year. This value is multiplied by the cost of electricity $11.6 \mathrm{c} / \mathrm{kWh}(\$ 1260 /$ year), and then multiplied by the $7 \%$ state tax. Therefore, a household in this location could save $\$ 1,348.21(=1260 * 1.07)$ in the first year. The project at the end of year 25 has $-\$ 8,632.74$ as a balance. According to these numbers, the NPV is equal to $\$ 15,869.46$, which is less than the initial cost for the system $(\$ 20,468.59)$, the IRR is $0.491 \%$, which is less than MARR $(3 \%)$, and the project balance is negative. Therefore, it can be concluded that installing a standard PV system in that area is not justified economically. Table 5 is a sample to show the cash flow and project balance calculation for the first location in the Lake County, Indiana.

Table 5: Cash Flows and Project Balances for a Standard System at the First Location in the Lake County, Indiana

\begin{tabular}{|c|c|c|c|c|c|}
\hline Year & Cash Flow & Project Balance & Year & Cash Flow & Project Balance \\
\hline 0 & $-\$ 20,468.59$ & $-\$ 20,468.59$ & 13 & $\$ 1,060.61$ & $-\$ 13,524.68$ \\
\hline 1 & $\$ 1,348.21$ & $-\$ 19,693.99$ & 14 & $\$ 1,039.62$ & $-\$ 12,859.62$ \\
\hline 2 & $\$ 1,321.52$ & $-\$ 18,923.64$ & 15 & $\$ 1,019.04$ & $-\$ 12,195.79$ \\
\hline 3 & $\$ 1,295.36$ & $-\$ 18,157.13$ & 16 & $\$ 998.87$ & $-\$ 11,532.84$ \\
\hline 4 & $\$ 1,269.72$ & $-\$ 17,394.03$ & 17 & $\$ 979.09$ & $-\$ 10,870.36$ \\
\hline 5 & $\$ 1,244.58$ & $-\$ 16,633.93$ & 18 & $\$ 959.71$ & $-\$ 10,207.96$ \\
\hline 6 & $\$ 1,219.95$ & $-\$ 15,876.40$ & 19 & $\$ 940.71$ & $-\$ 9,545.27$ \\
\hline 7 & $\$ 1,195.80$ & $-\$ 15,121.02$ & 20 & $-\$ 1,667.87$ & $-\$ 11,549.53$ \\
\hline 8 & $\$ 1,172.13$ & $-\$ 14,367.36$ & 21 & $\$ 903.84$ & $-\$ 10,965.06$ \\
\hline 9 & $\$ 1,148.92$ & $-\$ 13,614.99$ & 22 & $\$ 885.95$ & $-\$ 10,381.49$ \\
\hline 10 & $-\$ 1,463.78$ & $-\$ 15,531.14$ & 23 & $\$ 868.41$ & $-\$ 9,798.47$ \\
\hline 11 & $\$ 1,103.89$ & $-\$ 14,860.07$ & 24 & $\$ 851.22$ & $-\$ 9,215.67$ \\
\hline 12 & $\$ 1,082.03$ & $-\$ 14,191.38$ & 25 & $\$ 834.37$ & $-\$ 8,632.74$ \\
\hline
\end{tabular}

The same technique was used in all 18 locations to calculate the cash flow, project balance, NPV, and IRR. Table 6 summarizes the result of the economic analysis for all the selected counties in the State of Indiana. 
Table 6: Summary of the Study Results

\begin{tabular}{|l|c|c|c|c|c|}
\hline County & $\begin{array}{c}\text { Electricity } \\
\text { rate }\end{array}$ & $\begin{array}{c}\text { Generation of } \\
\text { Elec./ Year }\end{array}$ & $\begin{array}{c}\text { Project Balance by } \\
\text { end of year 25 }\end{array}$ & NPV & IRR \\
\hline Lake County, location 1 & 11.60 & $10864 \mathrm{kWh}$ & $-\$ 8,632.74$ & $\$ 15,869.46$ & $0.491 \%$ \\
\hline Lake County, location 2 & 11.50 & $10935 \mathrm{kWh}$ & $-\$ 8,746.96$ & $\$ 15,816.50$ & $0.460 \%$ \\
\hline Allen County, Location 1 & 7.30 & $10999 \mathrm{kWh}$ & $-\$ 23,677.31$ & $\$ 8,893.37$ & $-4.427 \%$ \\
\hline Allen County, Location 2 & 10.20 & $10880 \mathrm{kWh}$ & $-\$ 13,642.66$ & $\$ 13,546.39$ & $-0.944 \%$ \\
\hline Allen County, Location 3 & 9.90 & $10842 \mathrm{kWh}$ & $-\$ 14,869.06$ & $\$ 12,977.71$ & $-1.319 \%$ \\
\hline Allen County, Location 4 & 9.70 & $10890 \mathrm{kWh}$ & $-\$ 15,429.92$ & $\$ 12,717.64$ & $-1.494 \%$ \\
\hline Allen County, Location 5 & 10.00 & $11472 \mathrm{kWh}$ & $-\$ 12,481.77$ & $\$ 14,084.69$ & $-0.598 \%$ \\
\hline Tippecanoe County, Location 1 & 11.00 & $11043 \mathrm{kWh}$ & $-\$ 10,290.32$ & $\$ 15,100.85$ & $0.032 \%$ \\
\hline Tippecanoe County, Location 2 & 10.70 & $11358 \mathrm{kWh}$ & $-\$ 9,928.59$ & $\$ 15,268.58$ & $0.133 \%$ \\
\hline Tippecanoe County, Location 3 & 11.30 & $11277 \mathrm{kWh}$ & $-\$ 8,140.01$ & $\$ 16,097.93$ & $0.625 \%$ \\
\hline Tippecanoe County, Location 4 & 10.90 & $11539 \mathrm{kWh}$ & $-\$ 8,642.62$ & $\$ 15,864.88$ & $0.488 \%$ \\
\hline Marion County, Location 1 & 10.20 & $11194 \mathrm{kWh}$ & $-\$ 12,372.82$ & $\$ 14,135.20$ & $-0.566 \%$ \\
\hline Marion County, Location 2 & 9.70 & $11035 \mathrm{kWh}$ & $-\$ 14,884.85$ & $\$ 12,970.39$ & $-1.324 \%$ \\
\hline Monroe County, Location 1 & 10.40 & $11319 \mathrm{kWh}$ & $-\$ 11,437.39$ & $\$ 14,568.96$ & $-0.295 \%$ \\
\hline Monroe County, Location 2 & 11.50 & $11626 \mathrm{kWh}$ & $-\$ 6,026.24$ & $\$ 17,078.08$ & $1.186 \%$ \\
\hline Monroe County, Location 3 & 10.90 & $11297 \mathrm{kWh}$ & $-\$ 9,501.03$ & $\$ 15,466.84$ & $0.252 \%$ \\
\hline Vanderburgh County, Location 1 & 10.90 & $11543 \mathrm{kWh}$ & $-\$ 8,818.05$ & $\$ 15,783.53$ & $0.440 \%$ \\
\hline Vanderburgh County, Location 2 & 10.00 & $11942 \mathrm{kWh}$ & $-\$ 10,649.42$ & $\$ 14,934.34$ & $-0.070 \%$ \\
\hline
\end{tabular}

\section{CONCLUSION}

This study is intended to provide useful information to Indiana residents and homeowners considering the installation of a standard PV system as a means of reducing the cost of electricity. This study contributes to developing energy policies in the state of Indiana, by providing an independent analysis of the economic feasibility of using the grid-connected PV systems. The results of the study may help Indiana decision makers to evaluate the real needs and the applicable situations for using the residential PV system and may assist in the development of strategies and financial incentives that could make the PV system financially attractive.

This study found that the standard PV system does not produce a positive project balance and does not pay for itself within the life time of the system ( 25 years). The cost of solar PV is higher than the market valuation of the power it produces; thus, solar PV did not compete on the cost basis with the traditional competitive energy sources. Reducing the capital cost will make the standard PV system economically viable in Indiana. It is recommended that the policy makers in the State of Indiana may need to review the renewable energy incentive programs and make these programs more effective.

Even though the system does not seem to be economically viable in Indiana, environmental benefits could be gained from installing the system. For example, previous studies compared PV solar generation versus coalfueled generation; they estimated that, on an average, producing $1000 \mathrm{kWh}$ of electricity with solar power reduces emissions by nearly 8 pounds of sulfur dioxide, 5 pounds of nitrogen oxides, and more than 1400 pounds of carbon dioxide (Ibrahimov, 2013). Therefore, installing a standard PV system will enable its owner to reduce emissions by nearly $88(11 * 8)$ pounds of sulfur dioxide, $55(11 * 5)$ pounds of nitrogen oxides, and more than $15400\left(11^{*} 1400\right)$ pounds of carbon dioxide. This study may help the resident of Indiana understand the inter-relationship between energy, economy, and environment. By installing a standard PV system, residents of Indiana might be able to make their state a healthier place that is more suitable to raise their kids in healthy environments. In addition, energy efficiency and healthy environment are important factors that attract other people to live in the State of Indiana. The government should create educational programs that help in improving the residents' awareness regarding the environmental benefits of installing the standard PV system. Improving the Indiana residents' awareness will support the U. S. Department of Energy's efforts in reducing energy shortages and reducing America's dependence on foreign oil. Indiana residents should know that energy efficiency is beneficial for themselves, beneficial for their cities, and beneficial for the nation and the world even without immediate financial benefit. The following are recommendations for future research: 
1- The researcher recommends developing a future study to investigate the viability of one-axis and two axis PV grid-connected system and compare the result with the result of this study in order to develop a comprehensive picture for the viability of different types of PV systems.

2- Comparison study might be conducted to look at financial difference between the use of residential PV systems and residential wind turbines.

\section{REFERENCES}

Al-Odeh, M. 2013, "Feasibility Study of Residential Grid-Connected Solar", Terre Haute, IN: Indiana State.

Al-Odeh, M., Stergioulas, T., \& Badar, M. A. 2012, "Economic Analysis For Two-Axis Photovoltaic Tracking System For Indiana State University Building", NED University Journal of Research, vol. IX, no. 1, pp. 15-21.

Americas Power. 2012, "Energy Cost Impacts on American Families,2001-2012", Washington, DC: Americas Power.

Branker, K., Pathak, M. J. M., \& Pearce, J. M. 2011, "A review of solar photovoltaic levelized cost of electricity", Renewable and Sustainable Energy Reviews, vol. 15, no. 9, 4470-4482.

Dasgupta, P., \& Stiglitz, J. E. 1974, "Benefit-cost analysis and trade policies", The Journal of Political Economy, vol. 82, pp. 1-33.

De Reyck, B., Degraeve, Z., \& Vandenborre, R. 2008, "Project options valuation with net present value and decision tree analysis", European Journal of Operational Research, vol. 184, no. 1, 341-355.

Diamond, D. 2009, "The impact of government incentives for hybrid-electric vehicles: Evidence from US states", Energy Policy, vol. 37 , no. 3, pp. 972-983.

Dobos, A. P. 2014, "PV Watts version 5 manual", National Renewable Energy Laboratory, September.

Edison Electric Institute. 2006, "Rising Electricity Costs: A Challenge For Consumers, Regulators, and Utilities", Washington DC: Edison Electric Institute.

El-Bassiouny, D., \& Mohamed, E. K. A. 2012, "Solar energy cost efficiency: a simulated case study in the Egyptian context", International Journal of Economics and Accounting, vol. 3, no. 3-4, 322-343.

Electric Consumer 2011, "Member Installs First Solar System on REMC Lines", Indiana: Indiana Statewide Association of Rural Electric Cooperatives, Inc.

Energysage 2016, "What to Know About a Solar Panel Warranty", Retrieved from Energysage: http://news.energysage.com/shopping-solarpanels-pay-attention-to-solar-panels-warranty/

Energy Efficiency \& Renewable Energy 2008, "Solar Technologies Market Report" , Washington, DC: U.S. Department of Energy.

Energy Efficiency and Renewable Energy Clearinghouse 2012, "Energy Use of Some Typical Home Appliances", Merrifield, VA: Energy Efficiency and Renewable Energy Clearinghouse.

Ibrahimov, M. 2013, "Sustainable Energy Generation: What are the Perspectives", International Proceedings of Economics Development and Research, vol 59, no. 31, pp. 149-153.

IN.gov. 2013, "Demand Side Management Programs". Retrieved from Indiana Government website: http://www.in.gov/iurc/2571.htm

IN.gov. 2012, "Department of Local Government Finance". Retrieved from Indiana State: http://www.in.gov/dlgf/2337.htm

IN.gov. 2012, "OED: Overview", Retrieved from State of Indiana : http://www.in.gov/oed/2385.htm

Indiana Department of Revenue 2012, "Interest Rate for Calendar Year 2013". Indianapolis: Indiana Department of Revenue.

Indiana Utility Regulatory Commission 2012, "2011 Net Metering Required Reporting Summary". Retrieved from Indiana:

http://www.in.gov/iurc/files/2011_Net_Metering_Reporting_Summary.pdf

Indiana Utility Regulatory Commission 2012, "The Impacts of Federal Environmental Regulations on Indiana Electricity Prices", Indianapolis, Indiana: Indiana Utility Regulatory Commission.

Jha, A. R. 2010, "Solar Cell Technology and Applications", Boca Raton, FL: Auerbach Publications.

Khan, M. J., \& Iqbal, M. T. 2005, "Pre-feasibility study of stand-alone hybrid energy systems for applications in Newfoundland", Renewable energy, vol. 30, no. 6, pp. 835-854.

Kim, Y. H., Philippatos, G. C., \& Chung, K. H. 1986, "Evaluating investment in inventory policy: A net present value framework", The Engineering Economist, vol. 31, no. 2, pp. 119-136. 
Lagorse, J., Paire, D., \& Miraoui, A. 2009, "Sizing optimization of a stand-alone street lighting system powered by a hybrid system using fuel cell, PV and battery", Renewable Energy, vol. 34, no. 3, pp. 683-691

Nemet, G. F. 2009, "Demand-pull, technology-push, and government-led incentives for non-incremental technical change", Research Policy, vol. 38, no. 5, pp. 700-709.

Newnan, D., Eschenbach, T., \& Lavelle, J. 2011, "Engineering Economic Analysis", USA: Oxford University Press.

Purdue University. 2008, "Indiana electricity rates", Retrieved from Purdue University: https://news.uns.purdue.edu/x/2008a/080102GothamElectricity.html

Rosen, M. A., \& Dincer, I. 2003, "Exergy cost energy mass analysis of thermal systems and processes", Energy Conversion and Management, vol. 44, no. 10, pp. 1633-1651.

Safaei, A., Freire, F., \& Antunes, C. H. 2013, "A model for optimal energy planning of a commercial building integrating solar and cogeneration systems", Energy, vol. 61, November, pp. 211-223.

Solangi, K. H., Islam, M. R., Saidur, R., Rahim, N. A., \& Fayaz, H. 2011, "A review on global solar energy policy", Renewable and sustainable energy reviews, vol. 15, no. 4, pp. 2149-2163.

Tsoutsos, T., Frantzeskaki, N., \& Gekas, V. 2005, "Environmental impacts from the solar energy technologies", Energy Policy, vol. 33, no. 3, pp. 289-296.

Turney, D., \& Fthenakis, V. 2011, "Environmental impacts from the installation and operation of large-scale solar power plants", Renewable and Sustainable Energy Reviews, vol. 15 no. 6, pp. 3261-3270.

U.S. Department of Energy. 2012, "Photovoltaic Degradation Rates - An Analytical Review, DC: Office of Energy Efficiency \& Renewable Energy.

U.S. Energy Information Administration. 2012, "Average Price by State by Provider", USA: U.S. Energy Information Administration.

Wiser, R., Bolinger, M., \& Barbose, G. 2007, "Using the federal production tax credit to build a durable market for wind power in the United States", The Electricity Journal, vol. 20, no. 9, pp. 77-88. 